УДК 552 (571.5)

\title{
ЛИТОЛОГИЯ И КОЛЛЕКТОРСКИЕ СВОЙСТВА ДОКЕМБРИЙСКИХ ОТЛОЖЕНИЙ ЛЕНО-АНАБАРСКОЙ НЕФТЕГАЗОНОСНОЙ ОБЛАСТИ
}

\author{
Вараксина Ирина Валерьевна', \\ varaksinalV@ipgg.sbras.ru \\ Шаваров Роман Дмитриевич2, \\ shavarov_rd@irkutskoil.ru \\ 1 Институт нефртегазовой геологии и геофизики им. А.А. Трофимука Сибирского отделения Российской академии наук, \\ Россия, 630090, г. Новосибирск, пр. Академика Коптюга, 3. \\ 2000 «Иркутская нефртяная компания», \\ Россия, 664007, г. Иркутск, пр. Большой Литейный, 4.
}

\begin{abstract}
Актуальность исследования. В настоящее время одним из приоритетных направлений в расширении углеводородной базы России стало исследование и освоение её северных окраин. Лено-Анабарская нефтегазоносная область располагается на севере Сибирской платфрормы и характеризуется очень неравномерной геолого-геофизической изученностью. Наиболее слабо изучены докембрийские отложения, несмотря на их достаточно высокий коллекторский потенциал, а также прямые и косвенные признаки нефтегазоносности. Для более эффрективного проведения дальнейших геологоразведочных работ в этом регионе необходимо детальное изучение пробуренных ранее разрезов с выявлением литологических особенностей пород-коллекторов, условий их формирования и распространения.

Объект: отложения докембрия, вскрытые глубоким бурением на территории Лено-Анабарской нефттегазоносной области. Цель: на основе анализа состава, строения, обстановок осадконакопления и коллекторских свойств докембрийских отложений Лено-Анабарской нефртегазоносной области выделить перспективные резервуары углеводородов.

Методы: построение разрезов докембрийских отложений на основе детального макро- и микроскопического изучения кернового материала и данных ГИС; корреляция разрезов с учетом литологических, палеонтологических и геофизических данных; генетический анализ основных литологических типов пород и расшифровка условий их седиментации; оценка влияния седиментационных и постседиментационных фракторов на формирование коллекторских свойств; выделение уровней потенциальных коллекторов.

Результаты. Установлено, что докембрийский разрез представлен чередованием пачек карбонатных и терригенных пород, накопление которых происходило в широком спектре обстановок: от дельтовых до сублиторальных при существенном преобладании мелководно-морской седиментации. Выявлено, что в отложениях докембрия присутствуют потенциальнье породы-коллекторы, причем наиболее перспективные уровни приурочены к вендской части разреза.
\end{abstract}

\section{Ключевые слова:}

Лено-Анабарская нефртегазоносная область, литология, коллекторы, верхний рифрей, венд.

\section{Введение}

Начало интенсивного исследования Лено-Анабарской нефтегазоносной области (НГО) приходится на 50-70-е гг. XX в. В этот период был выполнен большой объем геолого-геофизических работ и пробурено несколько неглубоких скважин. В результате чего стало возможным обоснование высоких перспектив нефтегазоносности района $[1,2]$. С 80-90-х гг. была отработана сеть сейсмических профилей и пробурена серия параметрических скважин, вскрывших глубокие горизонты осадочного чехла, в которых были отмечены многочисленные битумо-, нефте- и газопроявления, а также получены интенсивные притоки пластовых вод с растворенным углеводородным газом. Несмотря на отсутствие выявленных залежей, многие исследователи считают, что исследуемый район обладает хорошим нефтегазовым потенциалом [3-8 и др.]. В пользу этого свидетельствуют промышленные притоки нефти в расположенной западнее Хатангской седловине, а также наличие Оленекского битумного поля в юго-восточном обрамлении ЛеноАнабарской НГО $[9,10]$. Однако в виду низкой изученности рассматриваемой территории глубоким бу- рением (всего шесть скважин) возникает необходимость более детального литологического изучения этих разрезов, направленного на выявление потенциальных резервуаров углеводородов. Результаты этих исследований приведены ниже и основаны на анализе кернового материала, отобранного сотрудниками Института нефтегазовой геологии и геофизики им. А.А. Трофимука СО РАН.

Геологическая позиция

и стратиграфия района исследования

Лено-Анабарская нефтегазоносная область занимает территорию Лено-Анабарского регионального прогиба, располагающегося в северной части Сибирской платформы, и входит в состав Лено-Тунгусской нефтегазоносной провинции (рис. 1) $[4,5,8]$. Осадочный чехол Лено-Анабарской НГО сложен верхнепротерозойскими, палеозойскими и мезозойскими отложениями, мощностью до 2-9 км, среди которых рифей-вендские породы занимают значительный объем. Объектом исследования стали отложения докембрия, вскрытые глубокими скважинами Чарчикская-1 и Хастахская- 930 в центральной части НГО, а также скважиной Бурская-3410, расположенной на её юж- 
ной окраине (рис. 1). Для Анабаро-Ленского прогиба характерно несовпадение рифейского и вендпалеозойского структурных планов, что обусловлено байкальским тектоногенезом $[4,7,8]$. Состав и толщина верхнерифейского комплекса в рассматриваемых разрезах достаточно выдержанные. Это свиде- тельствует о тектонически-спокойных условиях и слабой дислоцированности территории во время его формирования. Вендские отложения отличаются более изменчивым составом и строением, что предполагает более расчлененный рельеф области седиментации.

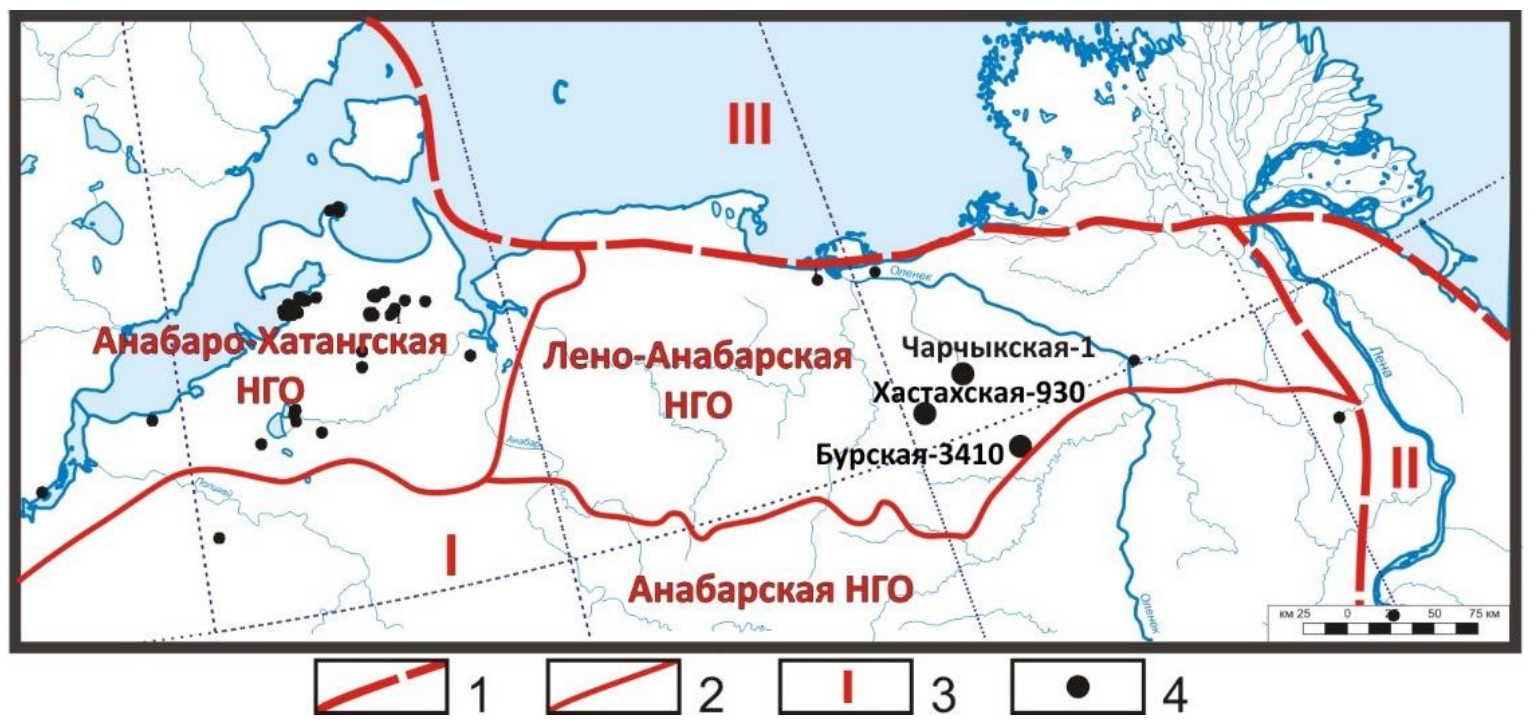

Pис. 1. Обзорная карта расположения Лено-Анабарской НГО на основе нефтегазогеологического районирования [5] Условные обозначения: 1 - границы нефтегазоносных провинций; 2 - границы нефтегазоносных областей; 3 - нефтегазоносные провинции (НГП): I - Лено-Тунгусская, II - Лено-Вилюйская, III - Лаптевская; 4 скважинь

Fig. 1. Overview map of the location of the Leno-Anabar oil-and-gas region based on petroleum geological zonation [5]. Legend: 1 - borders of petroleum provinces; 2 - borders of oil-and-gas regions; 3 - petroleum provinces (NGP): ILeno-Tunguska, II - Leno-Vilyui, III - Laptev; 4-wells

Относительно стратиграфического расчленения верхнепротерозойских отложений, вскрытых рассматриваемыми скважинами, существуют разные точки зрения. На первоначальном этапе изучения за основу была взята стратиграфическая схема Оленекского поднятия, согласно которой в этих разрезах были выделены все литостратиграфические подразделения с нижнего рифея до венда [11-13]. Эта схема достаточно популярна среди исследователей и в настоящее время $[4,7,14]$. Однако последние палеонтологические и сейсмостратиграфические данные достаточно убедительно свидетельствуют об отсутствии нижнесреднерифейских отложений в скважинах ЛеноАнабарского прогиба $[8,15]$. Поэтому в данной работе авторы опирались на новый вариант расчленения и корреляции [15], согласно которому наиболее полный разрез, вскрытый скважиной Бурская-3410, сложен тукуланской, куладинской, хастахской, таймылырской свитами верхнего рифея и двумя сериями венда: хорбусуонской и кессюсинской (рис. 2).

\section{Литологическая характеристика рифейского разреза}

В основании верхнерифейского разреза залегает тукуланская свита, подразделяющаяся на две подсвиты: нижнюю терригенную и верхнюю карбонатную (рис. 3). В скважине Бурская-3410 она представлена практически в полном объеме (вскрытая мощность 348 м). В нижней подсвите доминируют зеле- новато-серые аргиллиты, субгоризонтальнослоистые, реже косослоистые за счет тонких (от 5 до 20 мм) слойков алевролитов и мелкозернистых песчаников. Периодически фиксируются очень тонкие (5-10 мм) прослои глинистых доломитов. Верхняя подсвита, вскрытая также скв. Хастахская-930, полностью сложена доломитами светло-серыми с зеленоватым или коричневым оттенками, сильно перекристаллизованными до полной утраты первичной структуры, трещиноватыми, кавернозными. В кровле появляются прослои серых аргиллитов.

Вышележащая куладинская свита, несмотря на меньшую мощность (172-270 м), характеризуется аналогичным двучленным строением. Нижняя подсвита представлена переслаиванием аргиллитов тонкослоистых алевритистых, глинистых доломитов, известняков и песчаников. В южном разрезе (скв. Бурская-3410) преобладают песчаные породы. Песчаники буровато-серые мелко- и мелкосреднезернистые с однородно-массивной текстурой, изредка с тонкой горизонтальной и косой слоистостью за счет микрослойков темных аргиллитов. По составу в основном полевошпатово-литокластовокварцевые с глинисто-кварцевым, железистокарбонатным, реже регенерационным кварцевым цементами. В центральной части НГО (скв. Хастахская930) доминируют глинистые породы. Аргиллиты темно-зеленовато-серые тонкогоризонтальнослои- 
стые, часто алевритистые, в разной степени карбонатизированные. Наблюдается повсеместное возрастание содержания карбонатной составляющей в верх по разрезу. Верхняя подсвита почти полностью состоит из карбонатных пород с редкими прослоями в нижней и верхней частях известковых аргиллитов. Карбонат- ная часть представлена доломитами светло-серыми, иногда известковистыми, окремненными и слабо глинистыми, с реликтами зернистой и строматолитовой структур. Породы часто трещиновато-кавернозные, участками сильно кавернозные с примазками битуминозного вещества на стенках каверн.

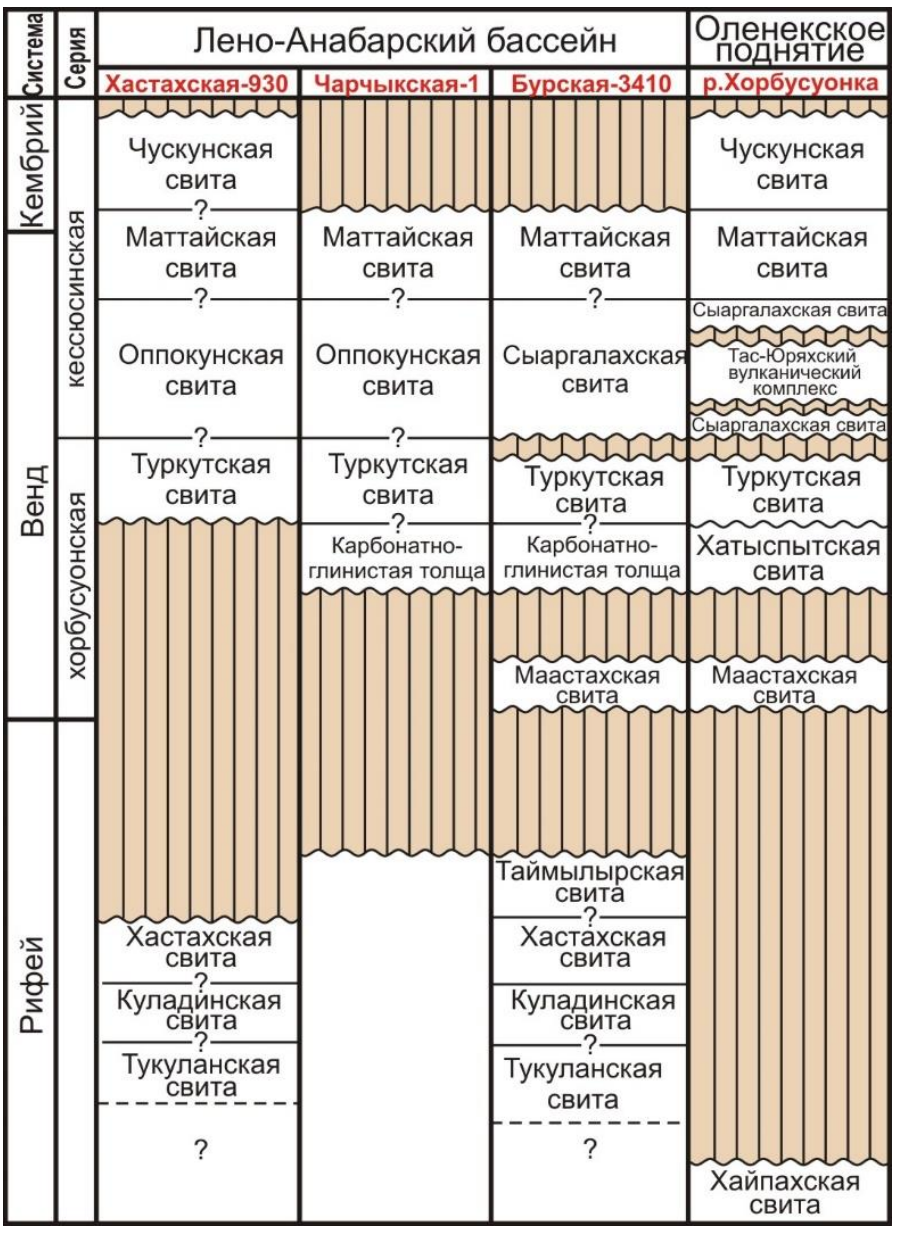

Рис. 2. Стратиграфическая схема неопротерозойских отложений Лено-Анабарского бассейна и прилегающего северо-западного склона Оленекского поднятия [15]

Fig. 2. Stratigraphic scheme of the Neoproterozoic deposits of Lena-Anabar Basin and the adjacent north-western slope of Olenek uplift [15]

Хастахская свита в отличие от нижележащих имеет относительно выдержанный состав. Кровля свиты в скв. Хастахская-930 размыта, но, учитывая сходство с южным разрезом, можно предположить, что её мощность не превышала 400 м. Свита выделяется более пестроцветной окраской и сложена переслаиванием песчаников, алевролитов и аргиллитов. В центральной части НГО в целом преобладают песчаные породы, причем разнозернистые, плохо сортированные, часто с примесью гравийного материала. На юге (скв. Бурская-3410) наблюдается уменьшение количества и мощности песчаных прослоев, а также доминирование более мелкозернистых разновидностей. По составу песчаники кварцевые, полевошпатово-кварцевые и полевошпатово-литокластовокварцевые с глинистым, железисто-глинистым, карбонатно-глинистым и реже регенерационным кварцевым цементами. Характерно развитие различных ти- пов слоистости: субгоризонтальной, косой, линзовидной, волнистой и флазерной. Алевролиты часто глинистые, нередко с тонкими горизонтальными и косыми слойками мелкозернистых песчаников. В нижней части свиты алевролиты линзовидно- и волнистослоистые, иногда со знаками ряби волнения. Аргиллиты в основном алевритистые, иногда доломитистые, с тонкой горизонтальной, реже линзовидной слоистостью, с редкими слойками мелкозернистых песчаников. В обоих разрезах присутствуют редкие прослои зеленовато-серых доломитов.

Завершает рифейский разрез таймылырская сви$m a$, сохранившаяся на юго-западе рассматриваемой территории (скв. Бурская-3410), вскрытая мощность которой 370 м. Прикровельная часть разреза пройдена без выноса керна, однако, судя по каротажу, верхняя граница свиты несогласная, что предполагает её частичный размыв в предвендское время. Вскрытые 
отложения представлены серыми доломитами, прослоями с многочисленными волнистыми слойками зеленовато-серых аргиллитов. Наблюдается переслаивание строматолитовых и зернистых (сгустково- комковатых, оолито-пизолитовых и интракластических) разновидностей. Участками породы окремненные, битуминозные, местами трещиноватые и кавернозные.

\section{Бурская-341}

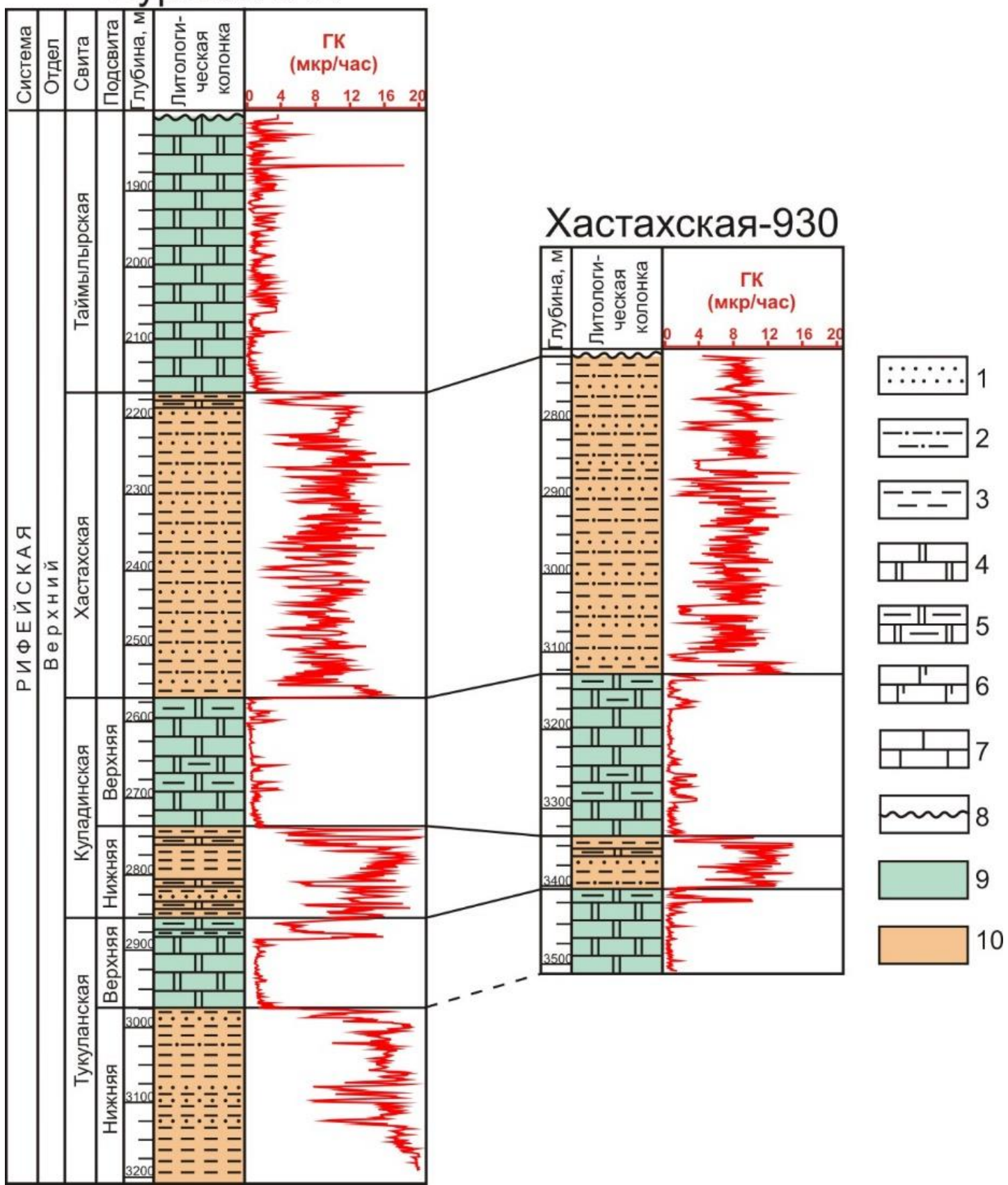

Рис. 3. Литолого-стратиграфическое расчленение и корреляция рифейских отложений. Условные обозначения: 1-7-nороды: 1 - песчаники, 2 - алевролитыл, 3 -аргиллиты, 4-доломиты, 5 - доломиты глинистые, 6 - доломиты известковые и известняки доломитовые, 7 - известняки; 8 - стратиграфический перерыв; 9, 10 литологические комплексы: 9 - карбонатные, 10 - терригенные

Fig. 3. Lithologic-stratigraphic division and correlation of Riphean deposits. Legend: 1-7 - rocks: 1 - sandstone, 2 siltstone, 3 -argillite, 4 -dolostone, 5 - shaly dolostone, 6 - calcareous dolostone and dolomite limestones, 7 limestone; 8 -stratigraphic interruption; 9, 10 -lithologic complexes: 9 - carbonate, 10 -terrigenous

\section{Литологическая характеристика вендского разреза}

Венд представлен двумя сериями (рис. 4). Нижняя хорбусуонская серия подразделяется на три свиты. В основании залегает маастахская свита, выделен- ная в скв. Бурская-3410, мощностью 60 м, сложенная бурыми и зеленовато-серыми алевролитами, алевропесчаниками и песчаниками. Песчаники среднемелкозернистые плохо сортированные, полевошпато- 
во-литокластово-кварцевые с карбонатно-железистым цементом. Породы горизонтально- и косослоистые. В разрезах центральной части НГО свита отсутствует вследствие размыва, который также частично уничтожил её отложения на юге.

Выше с перерывом залегает карбонатноглинистая толщза, вскрытая в скважинах Бурская3410 (220 м) и Чарчикская-1 (110 м), являющаяся стратиграфическим аналогом хатыспытской свиты (рис. 2), выделенной на северо-западном склоне Оленекского поднятия в бассейне р. Хорбусуонка $[15,16]$. В составе толщи наблюдается переслаивание темносерых доломитов, доломитизированных известняков и зеленовато-серых доломитово-известковых аргиллитов. Карбонатная часть в южном разрезе представлена преимущественно доломитами, а севернее (скв. Чарчикская-1) преобладают известняки.

Верхняя туркутская свита представлена во всех разрезах и характеризуется изменчивой мощностью, но относительно выдержанным составом. Наблюдается сокращение мощности в западном и южном направлениях от 207 м (скв. Чарчикская-1) до 118 м (скв. Хастахская-930) и 160 м (скв. Бурская-3410).
Свита сложена серыми доломитами в разной степени известковистыми и известняками доломитизированными. Наблюдается переслаивание строматолитовых, микрофитолитовых, микритовых и зернистых (с комками и интракластами) литотипов. В породах фиксируются многочисленные стилолиты, по которым развивается битуминозное вещество, а также трещины и каверны выщелачивания. В наиболее мощном разрезе (скв. Чарчкская-1) в подошве залегают чёрные битуминозные, кавернозные известняки. Отдельные каверны достигают 25 см. На свежем сколе в керне фиксируется характерный запах УВ.

Кессюсинская серия имеет двучленное строение. В центральной части НГО в её основании залегает существенно глинистая оппокунская свита (мощностью 190-290 м), в составе которой доминируют пестроцветные аргиллиты. Породы горизонтально, волнисто и косослоистые, часто известковистые, с прослоями известняков, находятся в тонком переслаивании с алевролитами и песчаниками. В южном разрезе оппокунской свите стратиграфически соответствует преимущественно песчанистая сыларгалахская свита, мощность которой значительно меньше (30 м).

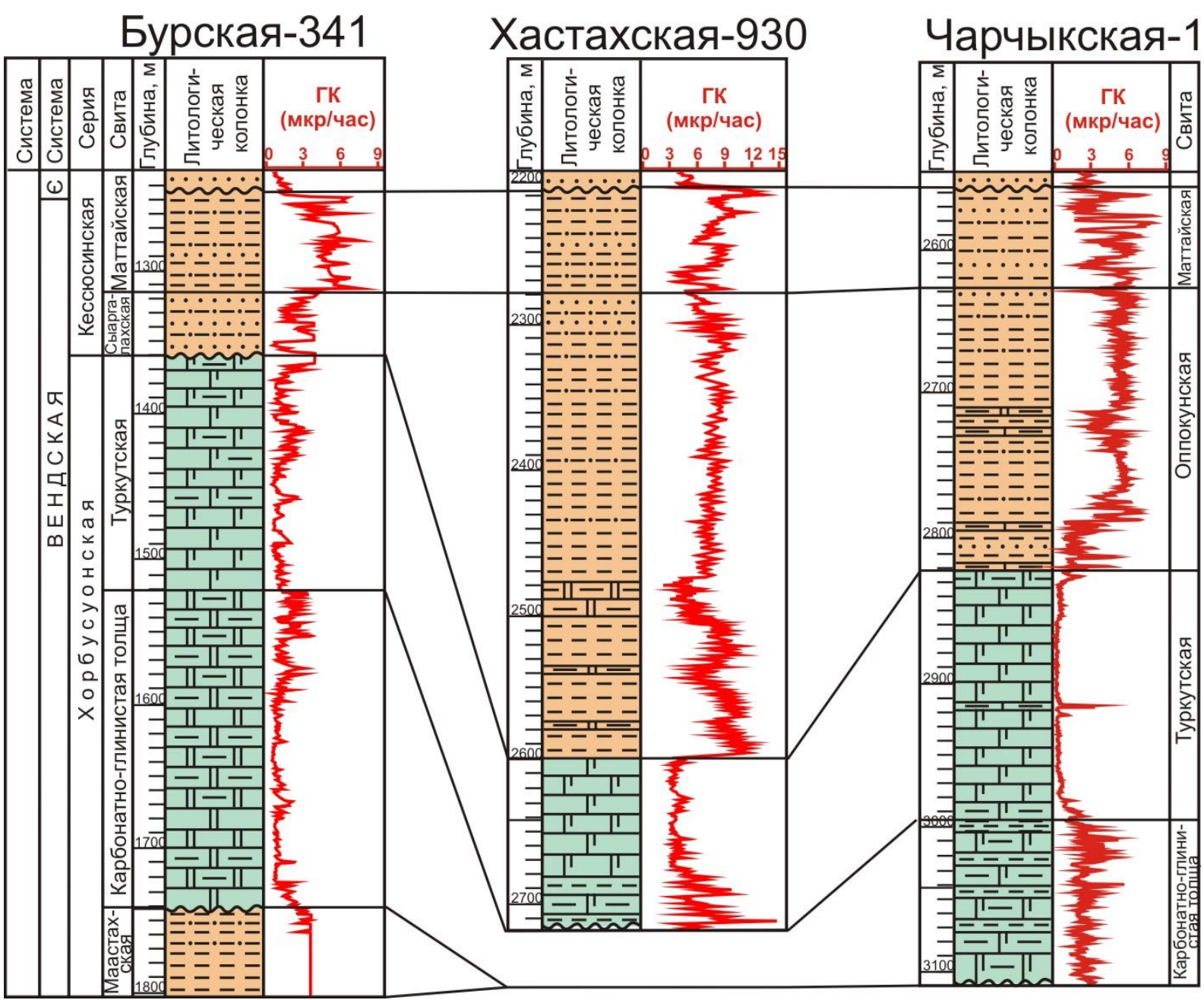

Рис. 4. Литолого-стратиграфическое расчленение и корреляция вендских отложений. Условные обозначения - на puc. 3

Fig. 4. Lithologic-stratigraphic division and correlation of the Vendian deposits. Symbols see in Fig. 3 
Завершается серия маттайской свитой (мощностью 70-75 м), возраст которой оценивается как венднижнекембрийский. Свита сложена переслаиванием зеленовато-серых и бурых алевролитов и аргиллитов, зеленовато-серых мелкозернистых и среднекрупнозернистых плохо сортированных песчаников. Породы часто известковистые, горизонтально и косослоистые, участками биотурбированные. Песчаники плохо сортированные, прослоями гравелитистые, нередко с интракластами аргиллитов, по составу литокластово-кварцевые с карбонатно-кварцевым и железисто-карбонатным цементами.

\section{Обстановки седиментации}

Анализ состава пород и их структурно-текстурных характеристик позволил реконструировать обстановки осадконакопления, существовавшие на территории исследования в позднерифейское и вендское время.

На протяжении всего позднего рифея седиментация происходила главным образом в относительно мелководных обстановках, но её характер неоднократно менялся, что отразилось в чередовании комплексов с доминированием терригенных или карбонатных пород. Формирование тукуланской свиты, имеющей двучленное строение, на раннем этапе происходило в относительной глубоководной части сублиторали открытого шельфа, где накапливались глинистые отложения. На позднем этапе привнос глинистого материала в бассейн значительно уменьшился, и на открытом низкоэнергетическом шельфе стали отлагаться преимущественно карбонатные осадки. В начале накопления куландинской свиты на фоне усиления терригенного стока и постепенного углубления шельфа произошел переход к карбонатно-глинистой седиментации. Последующее понижение уровня моря привело к восстановлению карбонатного режима осадконакопления. Верхнекуландинская подсвита характеризуется развитием оолитово-интракластических баровых комплексов и строматолитовых покровов литоральной зоны карбонатного шельфа. Во время формирования хаастахской свиты в результате очередной активизации сноса кластического материала стали доминировать терригенные фации распределительных каналов дельт, приливно-отливных баровых проток и песчаных баров. В таймылырское время режим карбонатной седиментации возобновляется, и на шельфе накапливаются строматолитовые ламиниты и оолитопизолито-интракластические отложения, соответствующие приливно-отливной обстановке. В конце рифея территория подверглась осушению и эррозии, глубина которой в центральной части Лено-Анабарской НГО (скв. Хастахская-930) была больше, чем на юге (скв. Бурская-3410).

В раннем венде в результате наступления моря в районе исследования устанавливаются прибрежноморские обстановки, в которых накапливаются алевро-песчаные отложения маастахской свиты. Отсутствие свиты в центральных разрезах НГО объясняется наличием крупного регионального внутривендского перерыва, после которого сформировалась карбонатно-глинистая толща. Преобладание в её составе пород глинистых известняков и характерные осадочные текстуры указывают на формирование отложений в обстановках, относительно удаленных от береговой линии и приближенных к области глубокого шельфа, наличие которой предполагается на северовостоке $[7,17]$. В туркутское время наблюдается обмеление карбонатного шельфа, о чем свидетельствует накопление биоморфных и микритово-зернистых доломитов, характерных для литоральной зоны [18]. Дальнейшее понижение уровня моря привело к кратковременному осушению южной окраины бассейна. Подъем уровня моря в раннекессюсинское время привёл к восстановлению относительно глубоководных обстановок дистального шельфа, в пределах которого сформировалась существенно известковоглинистая оппокунская свита. Периодически происходила активизация терригенного сноса, представленного разнозернистым песчаным материалом, содержание которого в южном разрезе существенно выше (сыргалахская свита), поскольку он более приближен к суше. Последующее обмеление бассейна в позднекессюсинское время привело к накоплению терригенной маттайской свиты, состав и текстурноструктурные особенности которой указывают на формирование в условиях прибрежного мелководья при активном влиянии приливно-отливных течений.

Таким образом, территория Лено-Анабарской НГО в позднерифейское и вендское время представляла собой открытый мелководный карбонатный шельф, на котором отложения приливно-отливных равнин, прибрежных отмелей и баров в периоды углубления сменялись карбонатно-глинистыми осадками дистальной части. Эпизодически происходила активизация сноса терригенного обломочного материала, который останавливал карбонатную седиментацию.

\section{Коллекторские свойства}

Периодическая смена обстановок осадконакопления обусловила неоднородное строение докембрийского разреза, что отразилось на распределении значений пористости и проницаемости. Анализ литологических особенностей и фильтрационно-емкостных свойств (ФЕС) рассматриваемых отложений позволил выделить уровни, которые являются потенциальными коллекторами.

В первую очередь в качестве коллекторов можно рассматривать карбонатные отложения, сформированные в пределах мелководного шельфа, которые слагают значительные по мощности интервалы (120160 м) в тукуланской и куладинской свитах рифейской части разреза, а также доминируют в туркутской свите венда. Фильтрационно-емкостные характеристики матрицы карбонатных пород, полученные при измерениях в лабораторных условиях, низкие. Пористость изменяется от 2 до $7 \%$, причем в рифейских отложениях преобладают значения около 2$3 \%$, а в туркутской свите около 5-7\%. Проницаемость не превышает $0,22 \times 10^{-3}$ мкм $^{2}$, но в туркутской свите в некоторых образцах проницаемость варьирует от 136 до $8000 \times 10^{-3}$ мкм $^{2}$. В пустотном пространстве матрицы в целом доминируют субкапиллярные поры 
радиусом менее 0,2 мкм, в доломитизированных известняках и доломитах размер пустот немного больше: 1-5 мкм, редко до 100 мкм. Однако изучение пород в керне показало, что они разбиты разнонаправленными открытыми трещинами, участками достаточно интенсивно (рис. 5, $a$ ). Кроме того, наблюдается широкое развитие микростилолитов, особенно в строматолитовых прослоях. Нередко фиксируются частично или полностью открытые вторичные пустоты, с расширениями до 25 мм, образованные за счет процессов растворения и приуроченные к трещинам и стилолитовым швам (рис. 5, б). Периодически отмечается битумонасыщение пустотного пространства (каверн, стилолитов и трещин), особенно в венде, что косвенно доказывает хорошие резервуарные качества этих пород (рис. 5, в). Вышеизложенное позволяет предположить наличие на этих уровнях каверновотрещинного типа коллектора.

Также к коллекторам с некоторой степенью условности можно отнести песчаные породы, которые занимают достаточно значительный объем в куладинской, хастахской, маастахской и маттайской свитах. Они редко формируют самостоятельные комплексы мощностью до 5-7 м, а обычно присутствуют в виде прослоев, толщиной от нескольких сантиметров до первых метров. Гранулометрический состав песчаников весьма разнообразен. Среди них отмечаются мелкозернистые, крупнозернистые и смешанные разновидности, нередко с примесью гравийного материала. Сортировка обломков обычно средняя или плохая, редко хорошая. Но коллекторские свойства песчаников контролируются не только гранулометрией, а в значительной степени типом цемента. Наиболее существенное сокращение пустотного пространства зафиксировано в песчаниках с глинистокарбонатным, железисто-карбонатным и карбонатным типами цемента (рис. 5, г, д). Таким образом, недостаточно хорошая сортировка, пёстрый гранулометрический состав и широкое развитие существенно карбонатных цементов определили относительно невысокие ФЕС песчаных горизонтов. Пористость в этих породах варьирует от 1,0 до $10 \%$, в большинстве образцов составляет 5-9 \%, проницаемость обычно не превышает $1 \times 10^{-3}$ мкм $^{2}$.

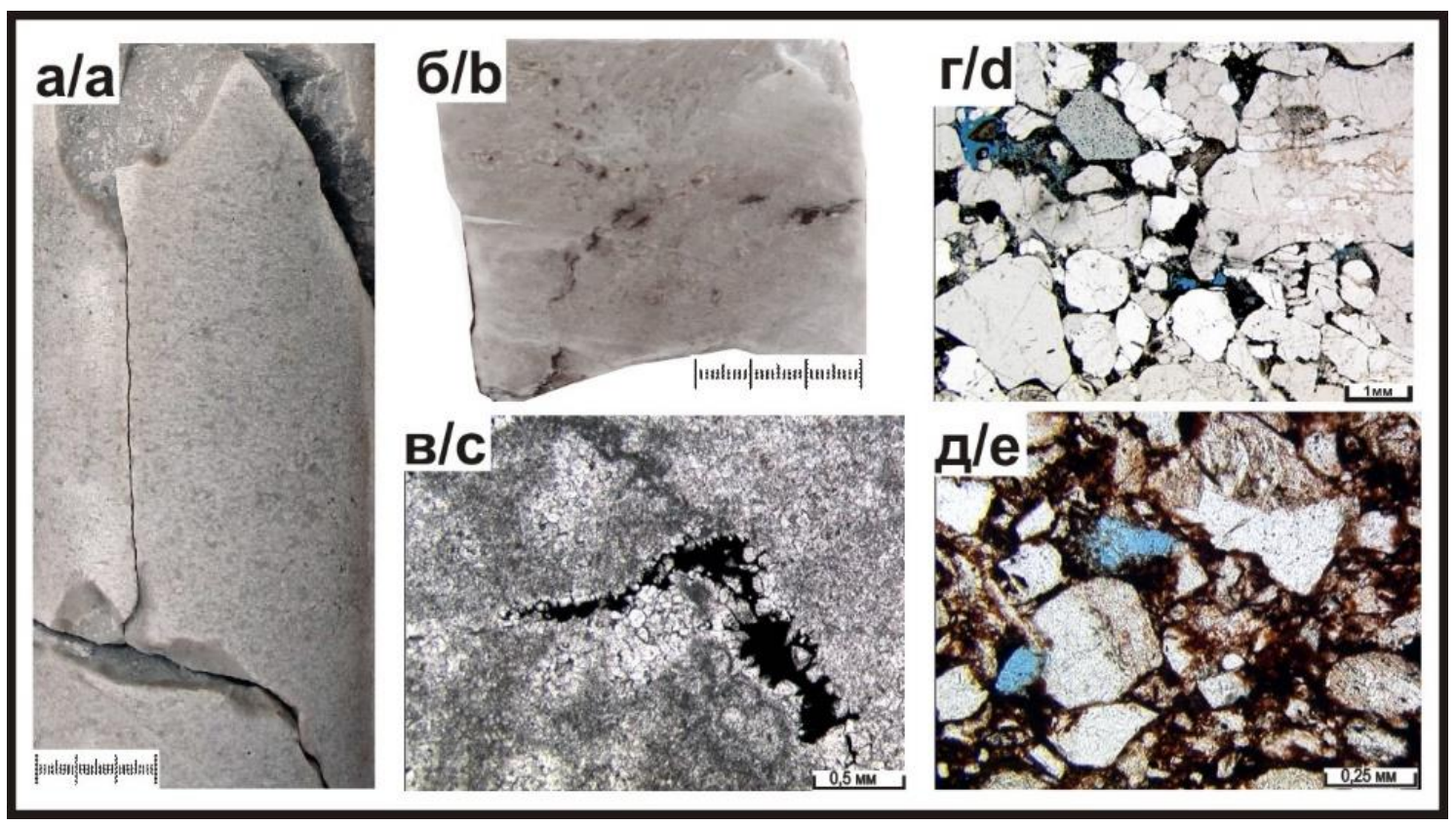

Puc. 5. Пустотное пространство потенциальных коллекторов: а) разнонаправленные трещцины в зернистом доломите (таймыльрская свита); б) поры и каверны выщелачивания в доломитизированном известняке (туркутская свита); в) каверна выщелачивания в доломите известковистом микрофитолитовом, выполненная битумом (туркутская свита); г) поры (синее) в квариевом гравелитистом песчанике глинистокарбонатным цементом (хастахская свита); д) поры (синее) в литокластово-кварцевом песчанике с карбонатно-железистым цементом (маастахская свита)

Fig. 5. Void space of potential collectors: a) multidirectional cracks in the dolomite grainstone (Taimylyr Formation); b) pores and leaching caverns in dolomitized limestone (Turkut Formation); c) leaching cavity in microphytolithic calcareous dolomite, filled by bitumen (Turkut Formation); d) pores (blue) in quartz gravelitic sandstone with claycarbonate cement (Khastakh Formation); e) pores (blue) in lithoclast-quartz sandstone with carbonate-ferruginous cement (Maastakh Formation)

\section{Заключение}

Проведенные исследования позволили установить следующее:

1. В районе Лено-Анабарской НГО докембрийский разрез представлен чередованием комплексов с доминированием терригенных или карбонатных пород, накопление которых происходило в широком спектре обстановок: от дельтовых до сублиторальных при существенном преобладании карбонатной мелководно-морской седиментации с 
эпизодами активного поступления силикокластического материала.

2. С точки зрения коллекторских свойств наибольший интерес представляют отложения мелководного шельфа. В первую очередь перспективные уровни связаны с карбонатными породами, которые хоть и имеют невысокие значения пористости и проницаемости матрицы, но осложнены многочисленными трещинами, стилолитами и кавернами, увеличивающими их фильтрационно-емкостные параметры. Наилучшими коллекторскими свойствами обладает туркутская свита венда, породы которой интенсивно насыщены битумом. Песчаные горизонты к перспективным объектам можно отнести условно в виду их относительно небольших мощностей и средних фильтрационно-емкостных характеристик.

3. Флюидоупорами для докембрийских резервуаров могут служить низкопористые и низкопроницаемые толщи аргиллитов и карбонатно-глинистых пород венд-палеозойского возраста. В качестве

\section{СПИСОК ЛИТЕРАТУРЬ}

1. Грамберг И.С. Перспективы нефтегазоносности севера Восточной Сибири и Северо-Востока СССР // Геологическое строение и перспективы нефтегазоносности восточной части Советской Арктики. - Л.: НИИГА, 1973. - С. 5-15.

2. Анциферов А.С., Бакин В.Е., Варламов И.П. Геология нефти и газа Сибирской платформы. - М.: Недра, 1981. - 552 с.

3. Дмитриевский А.Н., Еремин Н.А., Шабалин Н.А. Углеводородный потенциал арктической зоны Сибирской платформы // Геология, геофизика и разработка нефтяных и газовых месторождений. - 2018. - № 1. - С. 4-10.

4. Структурно-тектоническая характеристика и модель геологического строения неопротерозойско-фанерозойских отложений Анабаро-Ленской зоны / В.А. Конторович, А.Э. Конторович, И.А. Губин, А.М. Зотеев, В.В. Лапковский, Н.В. Малышев, М.В. Соловьев, Г.С Фрадкин // Геология и геофизика. - 2013. - Т. 54. - № 8. - С. 1253-1274.

5. Нефтегазогеологическое районирование Сибирской платформы (уточненная версия) / А.Э. Конторович, Л.М. Бурштейн В.И. Вальчак, И.А. Губин, А.О. Гордеева, Е.Н. Кузнецова, В.А Конторович, С.А. Моисеев, М.Ю. Скузоватов, А.М. Фомин // XIII Международный научный конгресс Интерэкспо ГЕОСибирь. - Новосибирск, 2017. - Т. 1. - С. 57-64

6. Геохимические критерии нефтегазоносности рифейпалеозойских отложений Лено-Анабарского регионального прогиба и сопредельных территорий / П.Н. Соболев, Д.С. Лежнин, И.А. Панарин, Е.Н. Гаврилова, А.М. Пименова // Геология, геофизика и разработка нефтяных и газовых месторождений. - 2019. - № 8 (332). - С. 62-74.

7. Углеводородные системы и перспективы нефтегазоносности Анабаро-Ленского прогиба / С.В. Фролов, Н.И. Коробова, Е.А. Бакай, Н.С. Курдина // Георесурсы. - 2017. - Спецвыпуск. Ч. 2. - С. 173-185. URL: http://doi.org/10.18599/grs.19.18 (дата обращения: 18.10.2019).

8. Сейсмогеологические модели и нефтегазоносность осадочных комплексов в арктических регионах Лено-Тунгусской нефтегазоносной провинции (Анабаро-Хатангская, ЛеноАнабарская нефтегазоносные области) / В.А. Конторович, А.Ю. Калинин, Л.М. Калинина, М.В. Соловьев // Геология нефти и газа. - 2019. - № 5. - С. 15-26.

9. Каширцев В.А. Органическая геохимия нафтидов востока Сибирской платформы. - Якутск: Изд-во СО РАН, 2003. $160 \mathrm{c}$.

10. Kashirtsev V.A., Hein F.J. Overview of natural bitumen fields of the Siberian platform, Olenek uplift, Eastern Siberia, Russia // Heavy-oil and Oil-sand Petroleum Systems in Alberta and Beyond. - 2013. - C. 509-529. нефтегазоматеринских отложений многие исследователи рассматривают хатыспытскую свиту венда Оленёкского поднятия, которая содержит повышенные концентрации органического вещества, генетически сходного с битумами туркутской свиты [19-21]. Перспективность верхнепротерозойских резервуаров на территории исследования косвенно подтверждается многочисленными скоплениями битумов на Оленекской, Восточно-Анабарской и других площадях севера Сибирской платформы $[9,10,16,19,22]$.

4. Таким образом, полученные результаты позволяют предположить на территории ЛеноАнабарской НГО наличие нескольких природных резервуаров в верхнепротерозойских отложениях, при этом наибольшим потенциалом обладает вендская часть разреза.

Работа выполнена при финансовой поддержке проекта ФНИ № 0331-2019-0021.

11. Граусман В.В., Рудавская В.А., Васильева Н.И. Стратиграфия верхнего докембрия и нижнего кембрия Оленекского поднятия // Отечественная геология. - 1996. - № 8. - С. 30-35.

12. Шишкин Б.Б., Исаев А.В. Особенности строения докембрийских и кембрийских отложений северо-востока Сибирской платформы // Геология и геофизика. - 1999. - Т. 40. - № 12. C. $1795-1807$.

13. Стратиграфия нефтегазоносных бассейнов Сибири. Рифей и венд Сибирской платформы и ее складчатого обрамления / Н.В. Мельников, Б.Б. Якшин, Б.Б. Шишкин, А.О. Ефимов, Г.А. Карлова, Л.И. Килина, Л.Н. Константинова, Б.Б. Кочнев, Б.Г. Краевский, П.Н. Мельников, К.Е. Наговицин, А.А. Постников, Л.В. Рябкова, А.А. Терлеев, Е.М. Хабаров. Новосибирск: Гео, 2005. - 428 с.

14. Старосельцев В.С., Шишкин Б.Б., Берилко Г.А. Актуальные проблемы геологии кембрийских и протерозойских отложений северо-востока Анабарской антеклизы в связи с нефтегазоносностью // Геология и минерально-сырьевые ресурсы Сибири. - 2016. - № 1 (25). - С. 44-56.

15. Revised Neoproterozoic and Terreneuvian stratigraphy of the Lena-Anabar Basin and north-western slope of the Olenek Uplift, Siberian Platform / K.E. Nagovitsin, V.I. Rogov, V.V. Marusin, G.A. Karlova, A.V. Kolesnikov, N.V. Bykova, D.V. Grazhdankin // Precambrian Research. - 2015. - V. 270. - P. 226-245.

16. Carbonaceous rocks of the Neoproterozoic (Vendian) Khatyspyt Formation as a possible source of oils in the northeastern Siberian Platform / T. Parfenova, V. Kashirtsev, L. Borisova, E. Ivanova, B. Kochnev, K. Nagovitsyn, V. Melenevsky // The $25^{\text {th }}$ International meeting on organic geochemistry. Book of abstracts. - Interlaken, Switzerland, 18-23 September 2011. - P. 435.

17. Meso-Neoproterozoic petroleum systems of the Eastern Siberian sedimentary basins / S.V. Frolov, G.G. Akhmanov, E.A. Bakay, N.V., Lubnina N.I. Korobova, E.E. Karnyushina, E.V. Kozlova // Precambrian Research. - 2015. - V. 259. - P. 95-113.

18. Davis R.A., Dalrymple R.W. Principles of Tidal Sedimentology. London: Springer Dordrecht Heidelberg London, 2012. - 609 p.

19. Chemostratigraphic constraints on Vendian-Cambrian basin dynamics, Notheast Siberian Craton / S.M. Pelechaty, J.P. Grotzinger, V.A. Kashirtsev, V.P. Zhernovsky // The Journal of Geology. - 1996. - V. 104. - P. 543-563.

20. Organic geochemistry of the Vendian Khatyspyt Formation (northeast of the Siberian Platphorm) / A. Kontorovich, T. Parfenova, V. Kashirtsev, N. Aksenova, E. Zubova, E. Ivanova, N. Yudina // $24^{\text {th }}$ International Meeting on Organic Geochemistry. Bremen, Germany, 6-11 September, 2009. - P. 174.

21. Redox-dependent distribution of early macro-organisms: evidence from the terminal Ediacaran Khatyspyt Formation in Arctic Siberia / H. Cui, D.V. Grazhdankin, S. Xiao, S. Peek, V.I. Rogov, N.V. Bykova, N.E. Sievers, X.-M. Liu, A.J. Kaufman // 
Palaeogeography, Palaeoclimatology, Palaeoecology. - 2016. V. 461. - P. 122-139.

22. Kim N., Kashirtsev V., Dzuba O. Organic geochemistry of naphthides of the Anabar-Khatanga saddle // The $25^{\text {th }}$ International
Meeting on Organic Geochemistry. - Interlaken, Switzerland, 18-23 September 2011. - P. 249.

\section{Информация об авторах}

Вараксина И.В., кандидат геолого-минералогических наук, старший научный сотрудник лаборатории седиментологии Института нефтегазовой геологии и геофизики им. А.А. Трофимука Сибирского отделения Российской академии наук.

Шаваров Р.Д., геолог департамента проектирования разработки месторождений, ООО «Иркутская нефтяная компания». 
UDC 552 (571.5)

\title{
LITHOLOGY AND RESERVOIR PROPERTIES OF PRECEMBRIAN DEPOSITS OF THE LENA-ANABAR OIL-AND-GAS REGION
}

\author{
Irina V. Varaksina ${ }^{1}$, \\ varaksinalV@ipgg.sbras.ru
}

Roman D. Shavarov², shavarov_rd@irkutskoil.ru

1 Trofimuk Institute of petroleum geology and geophysics of Siberian branch of Russian Academy of Sciences, 3 , Koptyug avenue, Novosibirsk, 630090, Russia.

2 Irkutsk Oil Company,

4, Bolshoy Liteiny avenue, Irkutsk, 664007, Russia.

The relevance. Nowadays, one of the priority directions in expanding the hydrocarbon base of Russia has become the research and development of its northern regions. The Lena-Anabar oil-and-gas region is located in the North part of the Siberian platform and is characterized by a very irregular geological and geophysical exploration. Precambrian deposits are the most poorly studied, despite their quite high reservoir potential, as well as direct and indirect signs of oil and gas potential. For more effective further geological exploration work in this region, a detailed study of previously drilled well sections is necessary, with the identification of lithological features of reservoir rocks, conditions for their formation and distribution.

The object: Precambrian deposits discovered by deep drilling on the territory of the Lena-Anabar oil-and-gas region.

The aim of the research is to identify perspective hydrocarbon reservoirs based on the analysis of the composition, structure, sedimentary environments and reservoir properties of Precambrian sediments of the Lena-Anabar oil-and-gas region.

Methods: creating sections of Precambrian deposits based on detailed macro- and microscopic analysis of core material and well logs data; correlation of sections in view of lithological, paleontological and geophysical data; genetic analysis of the main lithological types of rocks and clarification of their sedimentation conditions; estimation of the influence of sedimentation and post-sedimentation factors on formation of reservoir properties; identification of levels of potential reservoirs

Results. It was established that the Precambrian section is represented by the alternation of packs of carbonate and terrigenous rocks and its accumulation took place in a large range of environments: from delta to sublittoral, with a significant prevalence of shallow-water sedimentation. It was discovered that there are potential reservoir rocks in Precambrian sediments, and the most perspective levels are related to the Vendian part of the section.

\section{Key words:}

Lena-Anabar oil-and-gas region, lithology, reservoirs, Upper Riphean, Vendian.

The research was financially supported by the FSR project no. 0331-2019-0021.

\section{REFERENCES}

1. Gramberg I.S. Perspektivy neftegazonosnosti severa Vostochnoy Sibiri i Severo-Vostoka SSSR [Petroleum prospects of the north of Eastern Siberia and the North-East of the USSR]. Geologicheskoe stroenie $i$ perspektivy neftegazonosnosti vostochnoy chasti Sovetskoy Arktiki [Geological structure and oil and gas prospects of the eastern part of the Soviet Arctic]. Leningrad, NIIGA Publ., 1973. pp. 5-15.

2. Antsiferov A.S., Bakin V.E., Varlamov I.P. Geologiya nefti i gaza Sibirskoy platform [Geology of oil and gas of the Siberian platform]. Moscow, Nedra Publ., 1981. $552 \mathrm{p}$

3. Dmitrievskiy A.N., Eremin N.A., Shabalin N.A. Uglevodorodny potentsial arkticheskoy zony Sibirskoy platform [Hydrocarbon potential of the Arctic zone of the Siberian platform]. Geologiya, geofizika $i$ razrabotka neftyanykh $i$ gazovykh mestorozhdeniy, 2018, no. 1, pp. 4-10.

4. Kontorovich V.A., Kontorovich A.E., Gubin I.A., Zoteev A.M., Lapkovsky V.V., Malyshev N.A., Soloviev M.V., Fradkin G.S The Neoproterozoic-Phanerozoic section of the Anabar-Lena province: structural framework, geological model, and petroleum potential. Geology and Geophysics, 2013, vol. 54, no. 8, pp. 1253-1274. In Rus.

5. Kontorovich A.E., Burshteyn L.M., Valchak V.I., Gubin I.A., Gordeeva A.O., Kuznetsova E.N., Kontorovich V.A., Moiseev S.A., Skuzovatov M.Yu., Fomin A.M. Neftegazogeologicheskoe rayonirovanie Sibirskoy platformy (utochnennaya versiya) [Petroleum-geological regionalization of the Siberian platform]. XIII Mezhdunarodny nauchny kongress
Interekspo GEO-Sibir [XIII International Scientific Congress Interexpo GEO-Siberia]. Novosibirsk, 2017. Vol. 1, pp. 57-64.

6. Sobolev P.N., Lezhnin D.S., Panarin I.A., Gavrilova E.N., Pimenova A.M. Geochemical criteria of oil and gas potential of the Riphean-Paleozoic sediments of the Lena-Anabar regional trough and adjacent territories. Geologiya, geofizika i razrabotka neftyanyh i gazovyh mestorozhdenij, 2019, no. 8 (332), pp. 62-74. In Rus.

7. Frolov S.V., Korobova N.I., Bakay E.A., Kurdina N.S. Hydrocarbon systems and oil and gas potential prospects of the Anabar-Lena trough. Georesources, 2017. Special issue. Part 2, pp. 173-185. In Rus. Available at: http://doi.org/10.18599/grs.19.18 (accessed 18 October 2019).

8. Kontorovich V.A., Kalinin A.Yu., Kalinina L.M., Solovev M.V Seismogeological models and petroleum potential of sedimentary sequences in the Arctic regions of Lena-Tunguska petroleum province (Anabar-Khatanga, Lena-Anabar petroleum areas). Geology of oil and gas, 2019, no. 5, pp. 15-26. In Rus.

9. Kashirtsev V.A. Organicheskaya geokhimiya naftidov vostoka Sibirskoy platformy [Organic geochemistry of naphthides of the east of the Siberian platform]. Yakutsk, SO RAN Publ., 2003. $160 \mathrm{p}$

10. Kashirtsev V.A., Hein F.J. Overview of natural bitumen fields of the Siberian platform, Olenek uplift, Eastern Siberia, Russia. Heavy-oil and Oil-sand Petroleum Systems in Alberta and Beyond, 2013, pp. 509-529.

11. Grausman V.V., Rudavskaya V.A., Vasileva N.I. Stratigrafiya verkhnego dokembriya i nizhnego kembriya Olenekskogo 
podnyatiya [Stratigraphy of the Upper Precambrian and Lower Cambrian of the Olenek Uplift]. Otechestvennaya geologiya, 1996, no. 8, pp. 30-35.

12. Shishkin B.B., Isaev A.V. Structural features of Precambrian and Cambrian deposits of the North-East of the Siberian Platform. Geology and geophysics, 1999, vol. 40, no. 12, pp. 1795-1807. In Rus.

13. Melnikov N.V., Yakshin B.B., Shishkin B.B., Efimov A.O., Karlova G.A., Kilina L.I., Konstantinova L.N., Kochnev B.B., Kraevskij B.G., Melnikov P.N., Nagovicin K.E., Postnikov A.A., Ryabkova L.V., Terleev A.A., Habarov E.M. Stratigrafiya neftegazonosnykh basseynov Sibiri. Rifey $i$ vend Sibirskoy platformy $i$ ee skladchatogo obramleniya [Stratigraphy of the oil and gas basins of Siberia. Riphean and Vendian of the Siberian platform and its folded frame]. Novosibirsk, Geo Publ., 2005. $428 \mathrm{p}$.

14. Staroseltsev V.S., Shishkin B.B., Berilko G.A. Topical issues of geology of the Cambrian and Proterozoic deposits in the northeast of the Anabar anteclise in relation to petroleum content. Geology and mineral resources of Siberia, 2016, no. 1(25), pp. 44-56. In Rus.

15. Nagovitsin K.E., Rogov V.I., Marusin V.V., Karlova G.A., Kolesnikov A.V., Bykova N.V., Grazhdankin D.V. Revised Neoproterozoic and Terreneuvian stratigraphy of the Lena-Anabar Basin and north-western slope of the Olenek Uplift, Siberian Platform. Precambrian Research, 2015, vol. 270, pp. 226-245.

16. Parfenova T., Kashirtsev V., Borisova L., Ivanova E., Kochnev B., Nagovitsyn K., Melenevsky V. Carbonaceous rocks of the Neoproterozoic (Vendian) Khatyspyt Formation as a possible source of oils in the northeastern Siberian Platform. The $25^{\text {th }}$
International meeting on organic geochemistry. Book of abstracts. Interlaken, Switzerland, 18-23 September 2011. pp. 435.

17. Frolov S.V., Akhmanov G.G., Bakay E.A., Lubnina N.V., Korobova N.I., Karnyushina E.E., Kozlova E.V. MesoNeoproterozoic petroleum systems of the Eastern Siberian sedimentary basins. Precambrian Research, 2015, vol. 259, pp. 95-113.

18. Davis R.A., Dalrymple R.W. Principles of Tidal Sedimentology. London, Springer Dordrecht Heidelberg London, 2012. 609 p.

19. Pelechaty S.M., Grotzinger J.P., Kashirtsev V.A., Zhernovsky V.P. Chemostratigraphic constraints on Vendian-Cambrian basin dynamics, Notheast Siberian Craton. The Journal of Geology, 1996, vol. 104, pp. 543-563.

20. Kontorovich A., Parfenova T., Kashirtsev V., Aksenova N., Zubova E., Ivanova E., Yudina N. Organic geochemistry of the Vendian Khatyspyt Formation (northeast of the Siberian Platphorm). The $24^{\text {th }}$ International Meeting on Organic Geochemistry. Bremen, Germany, 6-11 September 2009. pp. 174.

21. Cui H., Grazhdankin D.V., Xiao S., Peek S., Rogov V.I., Bykova N.V., Sievers N.E., Liu X.-M, Kaufman A.J. Redox-dependent distribution of early macro-organisms: evidence from the terminal Ediacaran Khatyspyt Formation in Arctic Siberia. Palaeogeography, Palaeoclimatology, Palaeoecology, 2016, vol. 461, pp. 122-139.

22. Kim N., Kashirtsev V., Dzuba O. Organic geochemistry of naphthides of the Anabar-Khatanga saddle. The $25^{\text {th }}$ International Meeting on Organic Geochemistry. Interlaken, Switzerland, 18-23 September 2011. pp. 249

Received: 4 September 2020.

\section{Information abour the authors}

Irina V. Varaksina, Cand. Sc., senior researcher, Trofimuk Institute of petroleum geology and geophysics of Siberian branch of Russian Academy of Sciences.

Roman D. Shavarov, geologist, Irkutsk Oil Company. 